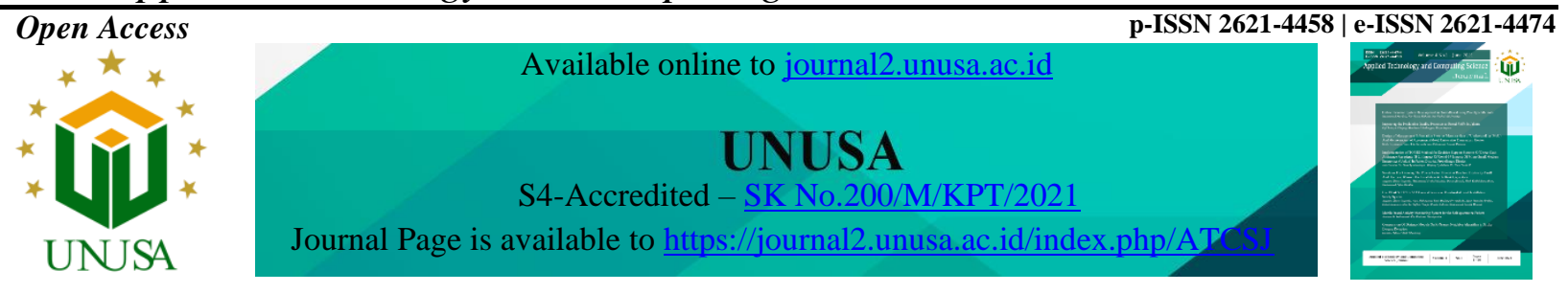

\title{
Design of Management Information Systems Memorandum of Understanding (MoU) And Memorandum of Agreement (MoA) Universitas Darussalam Gontor
}

\author{
Oddy Virgantara Putra ${ }^{1 *}$, Yoke Suryadarma ${ }^{2}$, Muhammad Arsyad Maulana ${ }^{3}$ \\ 1,2,3 Teknik Infomatika, Sains dan Teknologi, Universitas Darussalam Gontor, Indonesia \\ Jl. Raya Siman Km. 5, Siman, Ponorogo \\ 1*oddy@unida.gontor.ac.id, ${ }^{2}$ yoke.suryadarma@unida.gontor.ac.id, ${ }^{3}$ arsyadmaulana@ unida.gontor.ac.id
}

\begin{abstract}
Article history:
Received 14 June 2021

Revised 29 June 2021

Accepted 12 July 2021

Available online 31 July 2021

Keywords:

Information System,

MoU,

Single Page Application,

User Satisfaction.

Abstract

The Memorandum of Understanding (MoU) at Universitas Darussalam Gontor (UNIDA) is an important activity that can be proven by the number of MoUs that have been carried out. However, because the management of the MoU is still manual, there is a risk of damage, loss, and duplication of the MoU data. In this research, an information system for the Bureau of Cooperation, Alumni, and International Affairs UNIDA has been built to meet the bureau's needs in managing data correctly so that students and lecturers can utilize the data. The system is made in the form of a website using the concept of Model-View-Controller (MVC) and Single Page Application (SPA) by applying the SDLC (System Development Life Cycle) methodology. The study results show the satisfaction value of the respondent's assessment is at 4.11 on a scale of five, which means that this information system provides satisfaction to users. In the subsequent project research, this system can develop an authentication site for user security.
\end{abstract}

\section{(ㅇ) $(0)$} distribution, and reproduction in any medium, provided the original work is properly cited. (C)2021 by author.

\section{INTRODUCTION}

Universitas Darussalam (UNIDA) Gontor is a boarding school-based university that was established based on the Decree of the Minister of Education and Culture of the Government of the Republic of Indonesia no. 197 / E / O / 2014, which is currently progressing and developing quite rapidly. In its progress and development, UNIDA Gontor has collaborated as many as 253 universities consisting of 120 National and 116 International. The data is obtained based on the results of interviews conducted with Akhlis Azamuddin Tifani, S.H as the head of Bureau of Cooperation, Alumni and International Affairs (BKAUI) UNIDA.

The MoU and MoA carried out by UNIDA Gontor will never be separated from the things that have been done by the performance of the BKAUI UNIDA which plays a very good role in processing data and information on a regular basis. However, the processing of data and information that is carried out still often encounters problems such as the recording of cooperation in a form that is not yet integrated, which

$1^{*}$ Corresponding author 
causes the need for longer time in the search process, lack of accuracy in the validation of cooperation reports carried out, reporting that is not always updated because all units and institutions can establish cooperative relationships with other parties according to their respective needs, the vulnerability of damage and loss of physical documents, and the lack of information explaining the stages of submitting an MoU and MoA to this bureau, in particular all campus agencies and the general public.

In this problem, a decision can be made that an information system is needed that can manage and store data properly and can inform this data to students and lecturers so that it can ease the performance of the BKAUI UNIDA in developing the quality of education at the Universitas Darussalam Gontor.

\section{RELATED WORKS}

The first research entitled "Web-Based Cooperation Information System Development" case study "SEAMOLEC" by Castaka Agus Sugianto and Iqna Aulia using the research method of data collection as direct observation on the object of research and Waterfall as a system design method. Based on the results of the information system designed, it has produced positive things such as the preparation of a more organized cooperation statement document, the availability of document storage and digital filing, and assisting monitoring activities in planning activities [1].

The second study entitled "Public Relations Cooperation Management Information System at STMIK STIKOM Indonesia" by Welda and Brigida Arie Minartiningtyas, using research methods of literature study, observation and interviews on the object of research and Waterfall as a system design method. Positive things such as facilitating the work of public relations in storing and managing partner data, making it easier for public relations to archive evidence of cooperation in the form of an $\mathrm{MoU}$, and helping to provide information to public relations about the validity period of ongoing collaborations [2].

The third study entitled "Membangun Prototype Sistem Informasi Arsip Elektronik Surat Perjanjian Kerjasama Pada Business Support Departement" by Rusdiansyah using the research method of data collection as direct observation of the object of research, interviews, research literature from books and the internet as written data, and using the prototype model. in systems development. Based on the results of the information system that is designed to have produced positive things, such as processing cooperation agreements, it can be done anytime and from anywhere, including branches via the internet network, does not take up much space in document storage because documents are uploaded in scanned form in PDF format, users It will be easier to change document data because there is a notification feature that functions as a message, searching for data will be easier and faster [3].

The fourth study entitled "Application of Management Information Systems to Collaborate with Guardian Students" by Hanifa Zakia and Hadiyanto using qualitative field research research methods, namely this study intends to understand what phenomena experienced by researchers such as behavior, perceptions, events, and action. This study aims to provide an information space can be used by parents to see the development of their children's academic scores [4].

The fifth research entitled "Web-Based Vendor Cooperation Information System at PT. Pelabuhan Indonesia II (Persero) Cabang Panjang "by Bagus Prihadi, Ruki Rizal, Hendra Kurniawan, and Melda Agarina using the Rational Unified Process (RUP) research method, namely an iterative software development approach focused on case-directed architecture. Based on the results of the information system that is designed, it has produced positive things such as assisting the storage process and searching for data on vendor collaboration which was previously limited to documentation in the form of hardcopy and the use of applied computer applications, helping procurement employees to find out the maturity of vendor cooperation contracts, evaluation of work contracts can be done easily without having to see the physical files, this system helps in the creation of vendor cooperation reports, and documentation is maintained more safely [5] .

\section{A. Information Systems Management}

Management of Information System is a combination of information systems which consists of 3 elements, namely: organization, management, and technology. Management information systems play an important role in collecting and producing reliable, relevant, and organized data and information accurately 
and accurately, as well as a decision support system involving the use of people, documents, technology and procedures. The following is an explanation and the factors that make up the management information system, including:

a. Organization

Every organization has a goal that must be achieved with a unique system - each that can be accepted by its members. Every part of the organization has a function and purpose, different parts of the organization have different goals and functions. This point often creates conflicts as to how this part of the organization operates, gets resources, and gets rewarded. So that information appears from various perspectives, conflicts, compromises, and reasonable agreements.

b. Management

Management is a manager's job who is required to understand all circumstances to make the right decisions and plan actions to solve organizational problems. But managers have to do more than what is available, they are required to create new products for their organization with the knowledge and information gained. So that information technology is needed that can assist managers in making new products.

c. Technology

Information technology is a tool that can assist managers in helping their work, one of which is a computer which is a tool for entering, processing, and releasing information so that the information system is born[6].

\section{B. Memorandum of Undestanding (MoU)}

Memorandum of Understanding or more commonly known as MoU in Indonesian is defined as a Memorandum of Understanding which is the basis for drafting a contract based on the agreement of both parties and stated in written or oral form. The term Memorandum of Understanding (MoU) in the Black's Law Dictionary comes from a combination of words consisting of two words, namely the Memorandum "the basis for starting a formal contract arrangement" (is to serve as the basis of future formal contracts) "and Understanding" a statement agree indirectly to other agreements, whether written or oral (an implied agreement resulting from the express term of another agreement, whether written or oral) ". Overall that the Memorandum of Understanding can be interpreted as the preparation of a preliminary agreement agreed upon by both parties which is made to regulate and provide the opportunity to carry out a feasibility study for all parties before entering into a more detailed, detailed and contained agreement in a contract that will bind the parties later [7].

\section{Model-View-Controler (MVC)}

Model-View-Controller (MVC) is an architectural concept in web-based application development that was first published by XEROX PARC researchers, who worked in making the Smaltalk programming language in 1970-1980. This programming language model is developed based on the main components in building a web application into 3 major parts, namely manipulating data (Model) from the view or user interface (View) and how to process it (Controller).

\section{a. Model}

Model as a system that represents data structures. Model is a part that has functions to organize, prepare, manipulate, and organize data. The tasks that the model has include filling data into the database, updating data, deleting data, and so on. The model performs its functions by following the instructions from the controllers.

b. View

Management is a manager's job who is required to understand all circumstances to make the right decisions and plan actions to solve organizational problems. But managers have to do more than what is available, they are required to create new products for their organization with the knowledge and information gained. So that information technology is needed that can assist managers in making new products. 


\section{c. Controller}

Controller as a system that bridges model and view. Controller contains commands that function to process data and send it to a web page.

By using MVC, a developer will be greatly helped and facilitated in maintaining a program that has been mapped in a clear structure, so that changing the design will not change logic or data. Likewise, changing data will accidentally affect the display. Changing the program structure is also made easier because the changes occur in a separate part of the program.

\section{Single Page Aplication (SPA)}

Single Page Application (SPA) or it can be called a Single Page Application is a web application concept that works dynamically without having to refresh the page or in other words, the user makes all requests on a page without having to switch pages. Mechanically, the SPA system loads one page from the server and imposes a routing mechanism (switching pages) to the client without having to reach the server. So that system performance will increase and speed up page changes. The advantage of using the SPA system is that it reduces the need for network bandwidth because the SPA system is supported using a JavaScript library and a fast navigation process, because the data received from the server is in the form of JSON (JavaScript Object Notation) and is rendered asynchronously. An example of a JavaScript framework that supports the use of a SPA system is Vue js [1].

\section{METHODS}

\subsection{System Planning}

\section{A. Data Flow Diagram (DFD)}

Data Flow Diagrams (DFD) provide a visual display of the flow of data and information from a system. The visual of this DFD describes who is involved in the system, for more details, it can be seen in Figure 1.

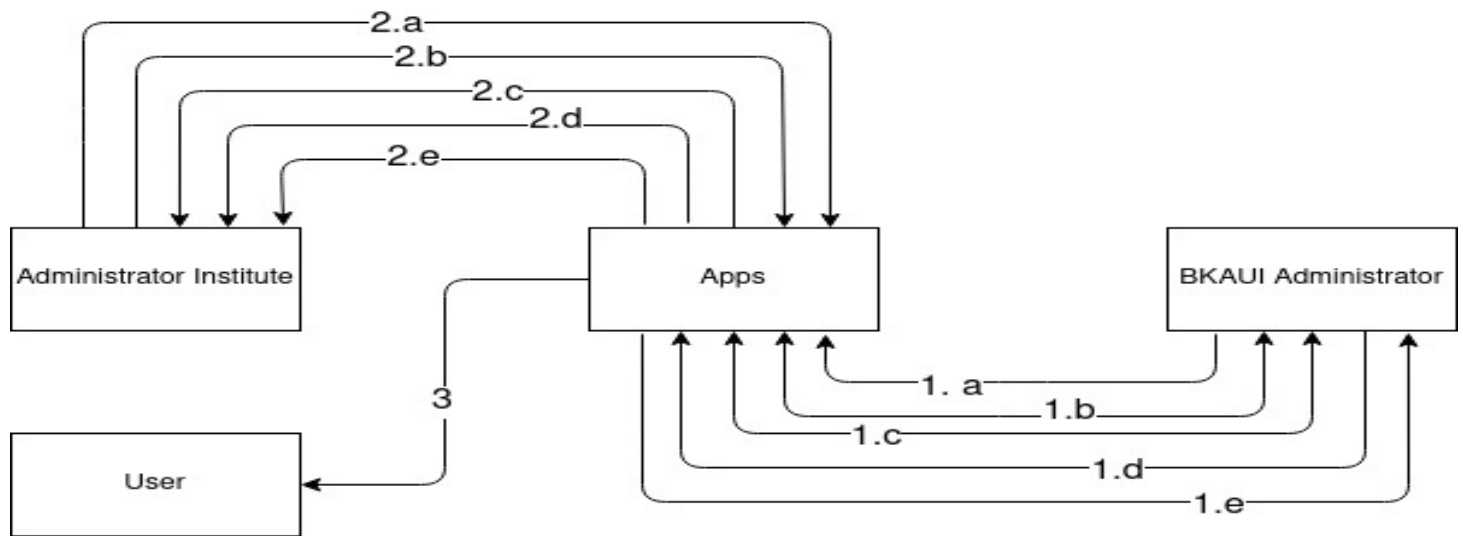

Figure. 1 Shows DFD in the management information system design MoU and MoA UNIDA Gontor in the form of user-based code. 1) Admin of the Bureau of Alumni, Cooperation, and International Affairs of UNIDA Gontor as super admin: 1.a) Input

data on MoU and MoA. 1.b) Edit, update, delete, view MoU and MoA data. 1.c) Download and upload the MoU and MoA submission forms. 1.d) Provide information on how to make MoU and MoA applications. 1.e) Dashboard of the progress of the MoU and MoA UNIDA Gontor. 2) Agency admin as admin. 2.a) Input MoU and MoA data. 2.b) Edit, update, view MoU and

MoA data. 2.c) download the MoU and MoA submission forms. 2.d) receive information on how to submit MoU and MoA submissions. 2.e) Dashboard of the progress of the MoU and MoA UNIDA Gontor. 3) Students and lecturers as users can see the system dashboard so they can find out the progress of the MoU and MoA at UNIDA Gontor

In the information system of the MoU and MoA UNIDA Gontor, there are three users, namely the Alumni and Cooperation Bureau admin as super admin, agency admin as admin, students and lecturers as users. The Alumni and Cooperation Bureau admin can input data on MoU and MoA submissions, edit, update, delete, view MoU and MoA data, confirm MoU and MoA submissions, provide notification to all 
UNIDA agencies Gontor, download and upload MoU and MoA submission forms, history submitting MoUs and MoAs, providing information on how to make MoU and MoA submissions, and the dashboard for the development of the MoU and MoA UNIDA Gontor, the agency admin as admin can input data (submission) MoU and MoA, edit, update, delete, view MoU and MoA data, receive notifications from the Bureau of Cooperation and Alumni, download forms for submitting MoUs and MoAs, history of submission of MoUs and MoAs, receive information on how to submit MoU and MoA submissions, and development dashboard for UNIDA Gontor MoU and MoA, for students and lecturers as users can see the system dashboard so that can find out the progress of the MoU and the MoA at UNIDA Gontor.

\section{B. User Regulations}

At this stage the researcher makes an access rights rule for the user which will be explained in the table below.

Table 1. Regulation of access rights in the management information system MoU / MoA UNIDA Gontor

\begin{tabular}{|l|c|c|c|}
\hline \multicolumn{1}{|c|}{ Usercase } & $\begin{array}{c}\text { BKAUI } \\
\text { UNIDA Gontor }\end{array}$ & $\begin{array}{c}\text { Administrator } \\
\text { Institute }\end{array}$ & $\begin{array}{c}\text { Student and } \\
\text { Lecturer }\end{array}$ \\
\hline Log in & $\checkmark$ & $\checkmark$ & \\
\hline View MoU/MoA & $\checkmark$ & $\checkmark$ & $\checkmark$ \\
\hline $\begin{array}{l}\text { Displaying information of How to Issue a } \\
\text { MoU/MoA }\end{array}$ & $\checkmark$ & $\checkmark$ & $\checkmark$ \\
\hline Download Application Form of MoU/MoA & $\checkmark$ & $\checkmark$ & $\checkmark$ \\
\hline Update Proposal Form of MoU/MoA & $\checkmark$ & & \\
\hline Add Application MoU/MOA & $\checkmark$ & $\checkmark$ & \\
\hline Edit MoU/MoA & $\checkmark$ & $\checkmark$ & \\
\hline Delete MoU/MoA & $\checkmark$ & $\checkmark$ & \\
\hline Download & $\checkmark$ & $\checkmark$ & \\
\hline Log Out & & & \\
\hline
\end{tabular}

\section{Use Case Diagram}

Descriptions of actors in the management information system of the UNIDA Gontor MoU / MoA are described in Table 2.

Table 2. User actor in the management information system MoU / MoA UNIDA Gontor

\begin{tabular}{|c|c|c|}
\hline No & Actor & Description \\
\hline 1 & $\begin{array}{l}\text { Admin of the Biro Alumni, Kerjasama, dan Urusan International } \\
\text { UNIDA Gontor (Super Admin) }\end{array}$ & Users who have full rights over the system \\
\hline 2 & Agency Admin (Admin) & $\begin{array}{l}\text { Users who almost have full rights to the system. Access } \\
\text { rights: Submission of MoU / MoA, download, Update, } \\
\text { View }\end{array}$ \\
\hline 3 & Students, Lecturers and the General (User) & $\begin{array}{l}\text { Users who only have Dashboard access and MoU / MoA } \\
\text { submission information }\end{array}$ \\
\hline
\end{tabular}


From Table 3.3, it is known that the management information system of the UNIDA Gontor MoU / MoA consists of three actors, namely the Admin of the Alumni Bureau, Cooperation, and International Affairs of UNIDA Gontor, agency administrators, and students / lecturers. The use case diagram of the MoU / MoA management information system design is presented in Figure 3.2.

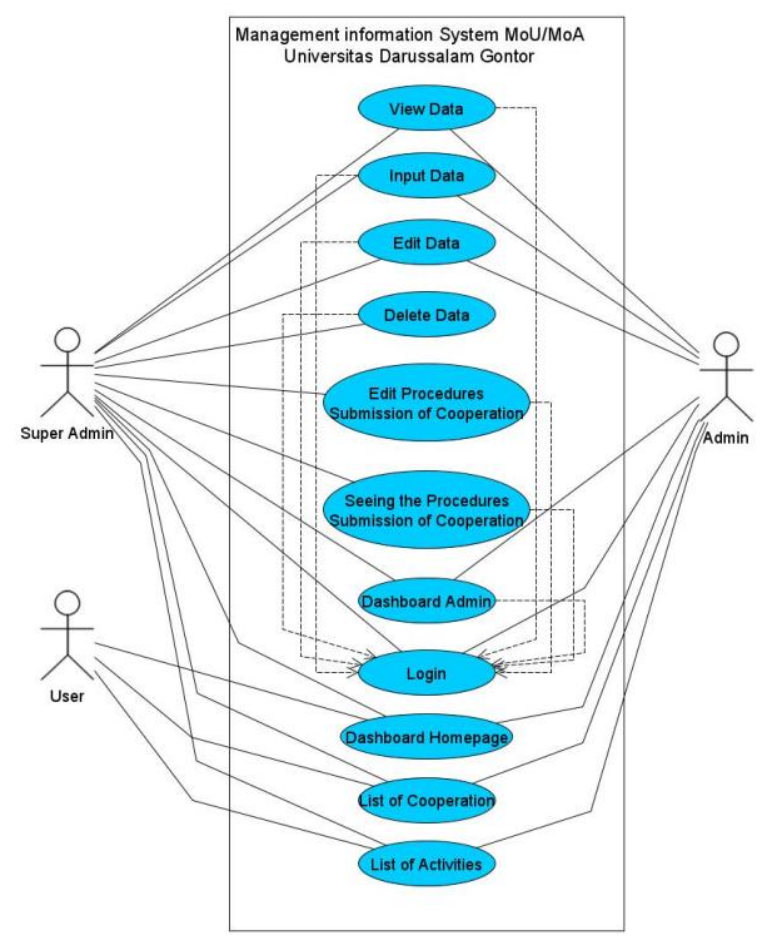

Figure 2. Use Case Diagram Universitas Darussalam Gontor

\subsection{Research Stages}

In carrying out the research on the Design of Management Information Systems Memorandum of Understanding (MoU) and Memorandum of Agreement (MoA) of Darussalam Gontor University, researchers used interview methods and literature studies to collect data and used the Model-ViewController (MVC) method by applying the System methodology. Development Life Cycle (SDLC) as shown in Figure 3.3, in system development which consists of fives stages, namelyPlanning Stages

The first research entitled "Web-Based Cooperation Information System Development" case study "SEAMOLEC" by Castaka Agus Sugianto and Iqna Aulia using the research method of data collection as direct observation on the object of research and Waterfall as a system design method. Based on the results of the information system designed, it has produced positive things such as the preparation of a more organized cooperation statement document, the availability of document storage and digital filing, and assisting monitoring activities in planning activities [5] .

\section{A. Planning Stages}

The first research entitled "Web-Based Cooperation Information System Development" case study "SEAMOLEC" by Castaka Agus Sugianto and Iqna Aulia using the research method of data collection as direct observation on the object of research and Waterfall as a system design method. Based on the results of the information system designed, it has produced positive things such as the preparation of a more organized cooperation statement document, the availability of document storage and digital filing, and assisting monitoring activities in planning activities [7] . 


\section{B. Stages of System Analysis}

The second study entitled "Public Relations Cooperation Management Information System at STMIK STIKOM Indonesia" by Welda and Brigida Arie Minartiningtyas, using research methods of literature study, observation and interviews on the object of research and Waterfall as a system design method. Positive things such as facilitating the work of public relations in storing and managing partner data, making it easier for public relations to archive evidence of cooperation in the form of an MoU, and helping to provide information to public relations about the validity period of ongoing collaborations.

\section{Stages of System Design and Development}

Many related reseaches used rapid development techniques such as Agile and Scrum Frameworks [8], [9]. However, in this work, we incorporated technique from [3]. The study entitled "Building a Prototype Electronic Archive Information System for a letter of cooperation agreement at the Business Support Department" by Rusdiansah using the research method of data collection as direct observation of the object of research, interviews, research literature from books and the internet as written data, and using the prototype model. in systems development. Based on the results of the information system that is designed to have produced positive things, such as processing cooperation agreements, it can be done anytime and from anywhere, including branches via the internet network, does not take up much space in document storage because documents are uploaded in scanned form in PDF format, users It will be easier to change document data because there is a notification feature that functions as a message, searching for data will be easier and faster.

\section{System Testing Stage}

At this stage the system must go through testing before it is used or published. The system testing phase must be carried out by conducting an experiment, whether the system has been running optimally or not. In his research, researchers will use the black box method. Black box is a testing method that focuses on the functional specifications of the software and to measure the level of user satisfaction, the researcher chooses to use the PIECES framework method.

\section{E. System of System Maintenance}

System maintenance is a very important part to be used as a reference at later date. Maintenance is the final stage and at the same time the beginning of a new phase, namely use. SDLC is not over at this stage. The resulting software must always be monitored to ensure the system is running perfectly.

\section{RESUlts AND Discussions}

\subsection{User Satisfaction Analysis}

Testing from users has the aim of seeing user satisfaction and impressions of the system being designed. This test is carried out by submitting a questionnaire to the staff of BKAUI UNIDA as users. Users are given all accounts, both those with admin and super permissions. The number of respondents who have tested the system will be presented in Table 3 .

Table 3. User Classification

\begin{tabular}{|c|c|c|}
\hline No & Respondents & Amount \\
\hline 1 & BKAUI UNIDA & 2 \\
\hline
\end{tabular}

In testing the researcher gave each respondent several questions to find out the response of each respondent in terms of ease, effectiveness and appearance of the information system that had been designed. Each question submitted is classified using the Likert scale method which has five value categories. The five categories are described in Table 4.

Table 4. Likert Scale 


\begin{tabular}{|l|l|l|}
\hline Answer Options & Abbreviation & Score \\
\hline Strongly agree & SA & 5 \\
\hline Agree & A & 4 \\
\hline Neutral & N & 3 \\
\hline Disagree & D & 2 \\
\hline Strongly Disagree & SD & 1 \\
\hline
\end{tabular}

The questionnaire that the researcher has distributed to users is structured according to the PIECES framework. Based on the value of satisfaction with the information system of the UNIDA Cooperation Bureau obtained from the results of questionnaires from users and using the Likert scale in the assessment, the formula is used to obtain the average value of the satisfaction rating are:

RK = Average of Questionnaire

JSK = Sum of Questionnaire Score

$\mathrm{JK} \quad=$ Sum of Questionnaire

In determining the level of satisfaction, researchers used one of the methods defined by Kaplan and Norton in Table 4.3.

Table 5. Questionnaire Score Range

\begin{tabular}{|c|c|l|}
\hline No & Range of value & Conclusion \\
\hline 1 & $4.92-5$ & Very satisfied \\
\hline 2 & $3.4-4.91$ & Satisfied \\
\hline 3 & $2.6-3.39$ & Quite satisfied \\
\hline 4 & $1.8-2.59$ & Not satisfied \\
\hline 5 & $1-1.79$ & Very Dissatisfied \\
\hline
\end{tabular}

With the provisions in measuring the level of satisfaction as described in Table 4.3. Then the obtained values are presented in Table 5 .

Table 5. Respondent's Response

\begin{tabular}{|c|c|c|c|c|c|c|}
\hline \multirow{2}{*}{ Indicators } & Respon & SA & A & $\mathrm{N}$ & $\mathrm{D}$ & $\mathrm{SD}$ \\
\hline & score & 5 & 4 & 3 & 2 & 1 \\
\hline \multirow{6}{*}{ Performance } & $\mathrm{R} 1$ & 1 & 1 & & & \\
\hline & $\mathrm{R} 2$ & & 2 & & & \\
\hline & R3 & & 2 & & & \\
\hline & R4 & & 1 & 1 & & \\
\hline & R5 & 1 & 1 & & & \\
\hline & R6 & 1 & 1 & & & \\
\hline \multirow{4}{*}{ Information and Data } & $\mathrm{R} 7$ & & 2 & & & \\
\hline & $\mathrm{R} 8$ & & 2 & & & \\
\hline & R9 & & 2 & & & \\
\hline & $\mathrm{R} 10$ & & 1 & 1 & & \\
\hline
\end{tabular}




\begin{tabular}{|l|l|l|l|l|l|l|}
\hline \multirow{4}{*}{ Economics } & $\mathrm{R} 11$ & & 2 & & & \\
\cline { 2 - 8 } & $\mathrm{R} 12$ & & 2 & & & \\
\cline { 2 - 8 } & $\mathrm{R} 13$ & 2 & & & & \\
\hline \multirow{5}{*}{ Control and Security } & $\mathrm{R} 14$ & & 2 & & & \\
\cline { 2 - 8 } & $\mathrm{R} 15$ & 1 & 1 & & & \\
\cline { 2 - 8 } & $\mathrm{R} 16$ & 1 & 1 & & & \\
\hline \multirow{5}{*}{ Efficiency } & $\mathrm{R} 17$ & & 2 & & & \\
\cline { 2 - 8 } & $\mathrm{R} 18$ & & 2 & & & \\
\cline { 2 - 8 } & $\mathrm{R} 19$ & 1 & 1 & & & \\
\hline \multirow{3}{*}{ Service } & $\mathrm{R} 20$ & & 2 & & & \\
\cline { 2 - 8 } & $\mathrm{R} 21$ & 1 & 1 & & & \\
\cline { 2 - 8 } & $\mathrm{R} 22$ & & & 2 & & \\
\hline
\end{tabular}

Questionnaire Results

$$
R K=\frac{181}{44}=4.11
$$

Based on the satisfaction calculation value above, the level of user satisfaction with the information system of the BKAUI UNIDA is included in the category "Satisfied". The following points out that this system provides a positive indication.

\section{CONCLUSIONS AND RECOMMENDATIONS}

The results of research on the information system of the UNIDA Cooperation Bureau can be concluded as follows:

1. Data processing applied to this management information system is integrated so that less time is needed in processing.

2. Data storage that is implemented can ensure the security and durability of data.

3. The information provided by the Bureau of Alumni, Cooperation, and International Affairs of UNIDA Gontor will, regarding the cooperation between the MoU and the MoA will be more accurate and real time.

The application runs smoothly according to user needs and has the predicate "Satisfied" from the user.

\section{REFERENCES}

[1] C. A. Sugianto and I. Aulia, "Pengembangan Sistem Informasi Kerjasama Berbasis Web Studi Kasus: Pada SEAMOLEC,” J. RESTI (Rekayasa Sist. dan Teknol. Informasi), vol. 1, no. 2, pp. 137-145, 2017.

[2] W. Welda and B. A. Minartiningtyas, "Sistem Informasi Pengelolaan Kerjasama Bidang Humas pada STMIK STIKOM Indonesia,” J. Sisfokom (Sistem Inf. Dan Komputer), vol. 6, no. 2, pp. 86-92, 2017.

[3] R. Rusdiansyah, "Membangun Prototype Sistem Informasi Arsip Elektronik Surat Perjanjian Kerjasama Pada Business Support Departement," J. Pilar Nusa Mandiri, vol. 14, no. 2, pp. 157-162, 2018.

[4] H. Zakia and H. Hadiyanto, "Penerapan Sistem Informasi Manajemen Untuk Menjalin Kerjasama dengan Wali Murid," JMKSP (Jurnal Manajemen, Kepemimpinan, dan Supervisi Pendidikan), vol. 5, no. 1, pp. 7176, 2020.

[5] B. Prihadi, R. Rizal, H. Kurniawan, and M. Agarina, "Sistem Informasi Kerjasama Vendor Berbasis Web Pada PT. Pelabuan Indonesia II (Persero) Cabang Panjang," SIMADA (Jurnal Sist. Inf. dan Manaj. Basis Data), vol. 3, no. 1, pp. 32-41, 2020. 
[6] C. L. Kenneth and P. L. Jane, Management Information System. Prentice Hall, 2012.

[7] G. N. Pratama, "Kekuatan Hukum Memorandum of Understanding (MoU) Dalam Hukum Perjanjian Indonesia," Verit. Justitia, vol. 2, no. 2, pp. 424-440, 2016.

[8] M. C. Sukron, R. P. N. Budiarti, and A. S. Kamil, "Implementation of Nadhir Online Registration System in Badan Wakaf Indonesia Using Agile Development Methods," Appl. Technol. Comput. Sci. J., vol. 3, no. 1, pp. 30-47, 2020, doi: 10.33086/atcsj.v3i1.1746.

[9] O. V. Putra, D. Muriyatmoko, and R. W. B. Mahendra, "IMPLEMENTASI GAMIFIKASI PADA SISTEM INFORMASI BEBAN KERJA DOSEN BERBASIS WEB MENGGUNAKAN METODE SCRUM," Pros. Penelit. Pendidik. dan Pengabdi. 2021, vol. 1, no. 1, pp. 323-331, 2021. 